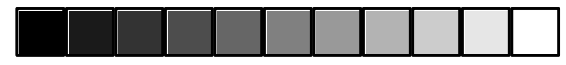

Zygmunt Bauman

\title{
Sociological \\ Enlightenment \\ - for whom, \\ about what?
}

By design or by default, all sociology performs the function of enlightenment. That function, though, can be addressed to the managers of public order or to men and women set in its frame and making their life choices within it. There is broad tendency in contemporary sociology to reorient the enlightenment task from the first addressee to the second. This tendency is accompanied by the retreat from the ambition to model sociological work after the natural-scientific pattern and an effort to incorporate into the body of sociological theory and practice of the fact of the endemic contingency, irregularity and under-determination of human conduct: in short, of human freedom of choice and human responsibility for the choices made or desisted.

Zygmunt Bauman is Emeritus Professor of Sociology at the Universities of Leeds and Warsaw.

DANSKSOCIOLOGI special issue, 1998 


\section{Two Enlightenments}

In his introductory words to this twoday celebration of the opening of the Sociology Programme in Aalborg, Jens Tonboe told us that now, once the birth pangs are over and technicalities out of the way, he "gradually encounters all the problems and tries to see them as challenges and possibilities". He gave us thus the definition of what human life sensibly lived is about, Henri Bergson defined living beings by their ability to turn obstacles into resources.

Professor Tonboe names some of those challenges, specific to sociology. He speaks of the "Increasing lack of ethics and moral... coupled with anxiety, and discontents" - "a surging unrest of anxiety, insecurity, even fear, dread and aggression". He then explains why these signs of our times are challenges to sociologists: Because of the loss of sense of connection between private fears and collective conditions and resolutions. We, the sociologists, must he says - "insist on micro in macro perspective" - and "bridge the polarisation between the personal-individual and the global". While doing so, we may, hopefully, "provide the confused individual... with a clarifying picture of his actual global social reality permitting him to produce, to change or recreate that reality from a more solid basis".

I could not put it better. In a nutshell, Jens Tonboe captured the nature of the changing enlightenment challenge confronting sociology: From enlightening the despot wishing to homogenise, to streamline and discipline - to enlightening the human individual about the infinite and infinitely varied collective entanglements of his choices and their consequences. From supplying the means to trim down human freedom, to offering help in proper use of that freedom and so reforging human fate into consciously embraced destiny and life vocation.

\section{Dream one: Science of human order}

Since it became conscious of its own separate existence and gave itself a name of its own, sociology was preoccupied with 'social order': That is, with pattern, structure, regularity in human affairs, and with all kinds of devices that bring them about and protect - that make or would make various human beings behave alike and in a predictable manner. In The Structure of Social Action, the book which was meant to sum up the first hundred years of sociological thought while charting the roads for further centuries of sociological inquiry, and seen by many people and for many years as astonishingly successful in both these tasks - Talcott Parsons informed his readers that since its inception sociology struggled with the solution to the 'Hobbesian problem', that is preoccupied with the mystery of people living with each other in a by-and-large orderly and peaceful fashion despite the fact that each one of them pursued wilfully his own gains and pleasures. This was a mystery, was it not? The humans, each one of them having a will of one's own and acting on that will to reach his or her own purposes, and yet doing remarkably similar things in similar circumstances, and doing them repeatedly - as if they did not have that free will at all or as if that free will which they had had been cancelled out and did not matter.... And cracking that mystery was for all founding fathers of sociology - for Marx, Durkheim or Weber alike - the major, perhaps the sole concern.

Cracking that mystery was - on the top of anything else - the essential condition of raising sociology to the level of science. All science, whatever its sub- 
ject-matter, proceeds in the same fashion: It seeks and discovers regularities behind apparent contingency of events, necessities behind accidents, determination behind contingency. All science is ultimately about how things must be - not just how they are, how they happen to be here or there, in this or another place. All science, in other words, reaches beyond the events which the scientists observe-proceeds beyond the observation of events down to the necessary connections between things, such as may be sometimes concealed, but never violated. All science, as they say, goes beneath the surface to the heart of the matter; or, as philosophers would say - beyond the phenomena, to the essence.

Sociology - since it deals with humans - is admittedly handicapped in this respect when compared with the scientists who study stars or rocks. The only hurdle those other scientists need to overcome is the sluggishness of their own imagination or errors committed in the course of their observations and experiments. If something appears to happen which does not look like what they expected to happen, they need only to go once more through their notes and re-test their laboratory equipment. They need not be, and they are not, haunted by the suspicion that perhaps the stars and the rocks themselves conspire to defy the iron laws that rule them; that they may choose to behave now one way, now another; that they may 'act' instead of simply 'behaving', be perverse, capricious, obstreperous or erratic and not at all subject to any laws.

Not having such doubts is the luxury available to the students of stars and rocks, but not, alas, to the students of human affairs. To pierce one's way to invariable patterns and rules through the thicket of diverse and often way- ward human actions takes more than the refinement of one's own tools of inquiry - a better phrased and structured questionnaire, for instance. It demands that the rule-disturbing power of human will, the profound difference between 'in order to' and 'because of', between the 'actions' which are guided by subjective motives and 'behaviour' which is determined by objective causes, are somehow argued away so that it may be declared that in the last account (and it is the last account that matters in science) such differences do not make any difference.

However sharply different in virtually every other aspect was the socialscientific activity which they wished to legislate into existence, the two founding fathers of modern sociology, Durkheim and Weber, were unanimous as to one injunction: Whatever else the social scientists do, they need to treat the lay accounts of living experience with suspicion. Never trust the laypersons reporting their motives. At best, they would have but a dim and foggy idea of what makes them tick; it is up to the social scientists to see their conduct coolly and clearly, and this thanks to the possession of qualities which laypersons, being laypersons, cannot have: Thanks to the ability to look beyond the realm of subjectively lived experience, see beyond the life-world of mortal individuals into the immortality of the group, "something greater than ourselves" (Durkheim); or thanks to the method of cleansing that life-world of the perishable, putrifiable fleshy parts so that its indestructible (since incorporeal) skeleton made of values, concepts and logical rules is laid bare (Weber). Both strategies are, however, poor substitutes for the natural scientist's radical break with the lay people's quotidianness. At the end of the long and tor- 
tuous pilgrimage to scientific serenity, the Durkheimian and Weberian scholars still speak of classes, states, statuses, power or prestige - not of the protons or electrons, black holes or big bangs. Neither of the two will ever fully succeed in their joint litigation to legally disempower the laypeople and to expropriate their objects of study, the laypersons', of their right of speech; the accomplishments which so matter-offactly fell into the hands of the 'natural scientist' is beyond their reach.

\section{Dream two: Natural science of the humans}

It seems today certain beyond reasonable doubt that not much of the naturalscientific certainty will ever rub off onto human studies. But it looks equally certain that virtually none of the typical human scientists' stomach pains are likely ever to be experienced at first hand by the student of nature (impostures intellectuals, the recent angry - as much as puzzled and contused - reaction of Alan Sokal and Jean Bricmont, was only to be expected!). Failing to note these two truths can be only blamed on the illusion of grandeur in the first case, or the frantic search of self-apology and forgiveness in the second.

Nature is numb. It was what it was, much in the shape it is now, well before the construction of the Tower of Babel was attempted and abandoned and even before Adam was told by God to give things their names.... Nature does not speak. It does not tell its own story - the story must be told by those speaking animals, the humans, who cast it as nature; and once the story has been told, there is no point in asking Nature to agree - the sole agreement which is sought by the story-tellers, and the only consent that can be found, is one between this story and other stories told by others and held correct.

Not by all others to be sure, not by any Tom, Dick and Harry; only by such others whose opinion count - those others who muster enough power to pronounce on the matter of correctness, of the truth of some stories and falsity of others. The great French philosopher of science Gaston Bachelard traced the beginning of science as the modern mind would recognise as being science and we understand it now to the appearance of first accounts of nature that started not from the discussion of commonly seen and familiar phenomena, but from the reference to concepts and theories known solely to the readers (and writers) of scientific books; in other words, to the division between the scientist and laypeople, between scientific discourse and vernacular, popular, daily speech - to what is called in philosophical language the 'self-referentiality' of scientific narrative. In order to check her account of laboratory or observatory experience, the scientists must refer to accounts given by other 'like them' - people speaking, from other laboratories or observatories. There would be no point in listening to what the rest - 'lay', 'non-specialist' people have to say; never crossing the door of a laboratory or observatory, such people have simply nothing of relevance to say - they have not experienced what can be experienced only inside the laboratory walls and thus have no story of their own to tell.

But the narratives of humanities, sociology including, are accounts of events that are experienced and given verbal form and talked about by 'ordinary' humans, by any humans; they are stories told about human experience accessible to all. And the scholarly tellers of such stories cannot be self-referential. This statement can be seen as a pleo- 


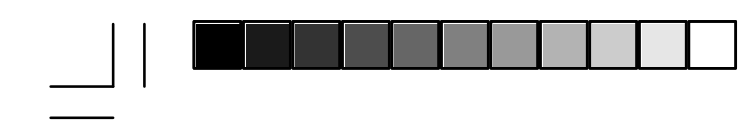

nasm, or as a definition of humanities: Humanities are the narratives that tell the story of the humans asspeaking subjects.

True, that quality of humans may be still disregarded, and is disregarded in many a story told about humans; but when it is disregarded it is not human experience - Erlebnis - that the story is about. In as far as they recognise their objects as speaking subjects, all humanities, sociology being no exception, are meeting places of stories; or, rather, they are stories told about stories. The stories with which the stories told by humanities must seek agreement are not just the stories spun by other 'human scientists', but the stories told by the objects - the heroes and the villains - of the stories. This circumstance alone casts already humanities into a situation radically different from those sought and found by 'hard science' - that is by investigative practice which cast their objects as $\mathrm{Na}$ ture, to wit a numb being, a being which does not have its own story to tell. The difference, roughly, is that between silence and the voice of the object. And the side-line is that in humanities, unlike in science, the dividing boundary between the experts and the laypeople, between those with the right to tell the stories with authority and those who are allowed only to listen and take note, is far from obvious and difficult to draw, let alone to defend.

Humanities neither need nor can deputise for the numb and speechless $\mathrm{Na}$ ture. The realities they explore are neither inarticulate nor speechless; on the contrary, they are made up of words, and the words are spoken. The realities with which sociologist have to deal had been human realities well before the telling of the stories by humanities took off; and they had been realities not in spite, but because they were 'human realities', given in human experience - lived through by humans, interpreted by humans, given names by humans, told and retold by humans. And so the coveted immunity to objections - called 'certainty' - does not come to humanities naturally, and obtaining it is not easy. In humanities, it is the matter of stories against stories; of the perpetual contest about the right to speak and validity of the stories, never ending skirmishes along the constantly drawn and redrawn boundary between competent speech and 'mere commonsense'. Humanities are not the immature younger brothers of 'better established' or 'better equipped' brands of science. They are an entirely different kind of activity altogether. They will never be 'like natural sciences'.

Never? This is not exactly true. The Humanities may (conceivably) rise to a scientific status in a world in which their speaking/interpreting human subjects descend (or are pushed) to the status of speechless objects; in a world remade after the likeness of concentration camps. In totalitarian societies which reduce their subjects to the order-following routine (or so it may seem for a time; as our recent experience shows, even in societies made after the pattern of concentration camps the inmates tend to recover sooner or later their voices). The snag is, though, that - as historical experience abundantly shows - in such a society not just the voice of their research objects, but of the humanities themselves tends to be stifled.... Little have we heard of scientific exploration of human mysteries accomplished under totalitarian conditions. The humanities cannot 'rise' to scientific status as long as they stay alive. They wither and die the moment the target comes near just like that legendary horse which, to the dismay of its owner, expired when 

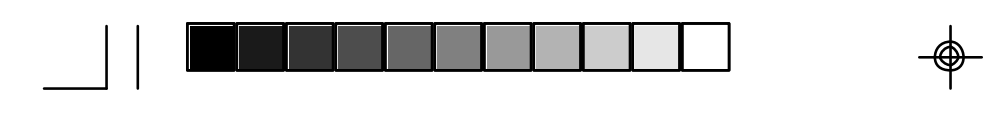

its training to do without food was coming close to successful completion.

An unresolvable paradox lies at the foundation of all humanities, sociology included. They are born out of an autonomous society - one that in Cornelius Castoriadis' words "self-institutes explicitly and reflexively", knowing well that all significations it creates have no guarantee external to itself; and yet all their efforts is directed towards closure of signification, which - if reached - would shut off political, philosophical, ethical as well as aesthetic questions. Humanities owe their raison d'être, their subject-matter, to the multitude of speaking subjects, the richness of their Erlebnisse, the variety of their stories; humanities have, so to speak, vested interests in the plurality of human experience, humanities feed on human variety and difference. And yet for the most part of their modern history humanities - sociology most prominent among them - tried hard to overcome that variety, to produce a story that would invalidate all other, previously told and even the yet untold stories; to replace variety with unity, discord with agreement, many voices with one voice. It was as if humanities were bent on suicide, wishing to cut off the branch on which they were sitting, to destroy the purpose of their very existence, to deprive themselves of the reason to be.

As to the sociologists - they were wary of degrading and shameful kinship with other humanities and angry if reminded of their family roots. They hotly denied sharing in the humanities' weaknesses, joined in the praise of science as not just a different, but superior, perhaps the only decent, kind of knowledge, and declared their determination to cross camps, whatever the price of admission might be. I myself, inadvertently, gave about two decades ago expres-

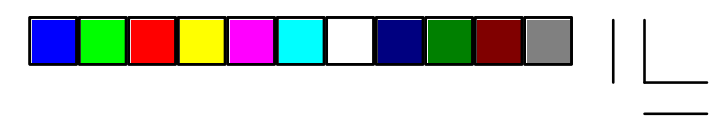

sion to that bizarre, hardly congruent stance when following the tip taken from Jürgen Habermas I concluded my Hermeneutics and Social Science with a statement that good sociology, like a good social worker, wishes to work itself out of its job; and that in the case of sociology this desire is acted upon in the effort to eliminate discord which is invariably a product of 'distorted communication', of misunderstandings and improper interpretations; and to replace conditions which bar understanding and induce wrong interpretations with other conditions, such as facilitate agreement and consensus.

\section{The great awakening}

And so we return to where we have started: Sociology, a truly modern invention, considered the discovery, the explanation and the promotion of order, regularity and predictability in human universe to be its prime task. In selecting order as its cognitive horizon and objective, sociology was in tune not only with modern science, but with modern politics as well.

The pre-modern state was a gamekeeper state: It presided over a 'natural order' of things, a 'divine chain of beings' that kept re-creating itself apparently without any human help and resented all human interference. Modern state is a gardener state; it is in charge of an order which otherwise would not come about or survive. For the 'natural order', which either collapsed or ceased to satisfy, the modern state substitutes an artificial one - one that must be legislated into existence and protected by the state's enforcing powers. For a modern state order is not a 'given', but a task. Modern state being what it is, order remains target of its acute attention and concern. Modern state is about setting the rules, defining patterns and main- 
taining them, administration, management, surveillance and supervision; it is also about staving off or preventing all deviance from the pattern and all breaching of the rule: Everything haphazard, erratic, un-anticipated and accidental.

That preoccupation of modern thought and practice with order was all the more obsessive for the fact that the reality of modern existence at any time was anything but orderly. And so that order with which modern thought and practice concerned themselves was at all times (to use Serge Moscovici's expression) a "regressive fantasy". It was indeed regressive, since it amounted to an idea and an effort to reduce complexity and variety of the human world, to cut down the number of stories told, to narrow down the range of alternative scenarios. And it was a fantasy - since the postulated patterns stayed always, stubbornly, a step or two ahead of reality and no reality already achieved matched exactly the form which it was prodded or prompted to assume.

But fantasising about order, and giving those fantasies a regressive bent, had anything but imagined, fantastic causes. It was (and it still is, to be sure) firmly rooted in the selfsame reality of modern existence which it strove to foreclose, reform and ultimately to overcome. The most distinctive mark of that reality is high degree of uncertainty. Uncertainty rules supreme and in every field of life; we are uncertain about the outcomes of our actions, about other people reactions to them, about propriety and wisdom of our decisions, about what the future has in store and how sound are our investment into it - we cannot be fully sure even about our own identity which is always an unfinished project, always a prospect as uncertain as everything else. Modern society was - long before Ulrich Beck gave it that name - a Risikogesellschaft, and living in such a society was and remains a Risikoleben.

Taking risks, particularly if you happen to be an adventurous spirit, is often exhilarating, but it may be also off-putting and unnerving, particularly if no resolutions of doubt is in sight. The dangers lurking in protracted and prospectless risk-taking are easy to see and have been widely noted and recorded. As Judith Square put it recently,

apparently secure walls, delimiting our sense of self, proved to be but permeable membranes.... In the face of insecurity about our limits and the realisation of the possibility of continuity, we all too often witness, not the celebration of new possibilities, but a retreat into fortress identities, the strategic use of the massive, regressive common denominators of essential identities. (Squares 1996:187).

It has become common to assume that the phenomenon Squares noted is essentially a new condition, due to a number of factors summed up in the concept of 'crisis of modernity'. Whether the volume of uncertainty involved in the lifeprocess has grown indeed radically in our times of post- or late-modernity is a moot question and it is not at all clear how one could go about answering it that is, how could one measure the volume of uncertainty 'objectively'. What does not seem, however, contentious, is that the perception of uncertainty, and so also the acuity with which it is felt and feared, has changed considerably; and this because our post- or late-modern condition is, as Sean Cubitt puts it, "a time without reassuring vision of 


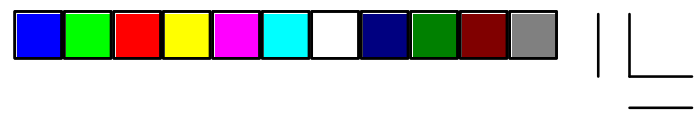

future enlightenment, rationality and wealth that inspired the architects of modernity" (Cubitt 1996:47). Or (to paraphrase Jonathan Freedman of Lund) because we are still modern but no more modernists, meaning that we entertain no reasonable and credible plans how to get rid of all that we experience as unpleasant and vexing in being modern. And, as Anthony Giddens sums up the current mood - we are particularly pessimistic about the chances of overcoming uncertainty as we realise that more often than not our uncertainty is a manufactured uncertainty and that more knowledge brings more, rather than less, of it.

Modernity promised to replace uncertainty with an orderly human universe in which futures can be planned and systematically pursued - and modern philosophers and political leaders alike set earnestly about fulfilling that promise. Sociologists followed suit hoping to assist the thinkers and the doers with reliable information about how human conduct of the desirable sort may be obtained and how to solicit the kind of compliance and conformity to the legally set rules that would put paid to interpretative disagreements and behavioural uncertainty. But the promise to conquer and annihilate uncertainty, if repeated nowadays, sounds hollow, while people resourceful enough to do the conquest are few and far between and altogether difficult to trust. There seem to be few takers for the orthodox sociology gifts - and a fast shrinking demand for the kind of product which the orthodox sociologists had become past masters in assembling.

American sociology used to set the pattern for sociological services to social order; no wonder that it is in the United States that one can hear the loudest alarms about crisis of sociology. Not just a 'coming crisis', of which Alvin Gouldner wrote quarter of a century ago hoping that spotting it would be the beginning of successful therapy, but a crisis which has already arrived, took roots all around and has no intention to move away. American sociology, as Anthony Giddens put it recently, faces the daunting task of "reconnecting to public policy-making agenda" (Giddens 1996:5). Presumably, it has lost its past connection which no more than twenty or thirty years ago seemed secure and well-nigh unbreakable; or, which seems to be more to the point, it is the public agenda itself that changed in a way which took the orthodox sociology unawares and unprepared, or a new sockets have been installed in the public policy sphere for which sociology has yet to find proper plugs and capacious enough cables.

\section{The new agenda}

And yet there is a public policy agenda to which sociology has all the chances of connecting, providing it recognizes the changed meanings of both 'public agenda' and 'connection' and draws from that recognition the right conclusions for its own strategy.

The new public agenda, still awaiting its public policy, is emerging in the void left by the past 'reassuring visions'. Indeed, as long as the diversity, ambivalence and contingency were cast by those visions as merely temporary irritants which soon would go away and be replaced by homogeneity -Eindeutigkeit and rationality, there was no strong motive to consider the consequences of uncertainty entailed in human condition. Uncertainty did not seem endemic to that condition, and 'acting under conditions of uncertainty' seemed both marginal and abnormal - and above all transient and curable. In the absence of 
such visions, however, it becomes ever more clear that uncertainty is here to stay, that acting without full inventory of the factors involved, without foolproof recipes and without knowledge of the whole range of consequences is the norm rather than a freak and avoidable happening and constitutes an integral, irremovable part of human condition. And the public agenda, whatever shape it might yet take, is going to be made by men and women aware of that and thus preoccupied first and foremost with the ways and means of choiceevaluation and risk-avoidance; by men and women increasingly aware of their freedom and everything that comes with freedom, including such unpleasant associates like perpetual insecurity, the necessity to choose and to accept one's own responsibility for the choices. The late Iosif Brodski defined a free man as one who does not complain in case of defeat.

However sociology might be connected to such a public agenda, it must plug itself to the hopes and worries of men and women cast in the condition of freedom.

The lot of a free agent is full of antinomies not easy to take stock of, let alone to disentangle. Consider, for instance, the contradictions of self-made identities which must be solid enough to be acknowledged as such and yet flexible enough not to bar freedom of movement in constantly changing, volatile circumstances. Or the precariousness of human partnerships, now burdened with greater than ever expectations yet poorly, if at all, institutionalised and therefore less resistant to the added burden. Or the sorry plight of the repossessed responsibility, sailing dangerously between the rocks of indifference and coercion. Or the fragility of all common action, which has solely the enthusiasm and dedication of the actors to rely on and yet needs more lasting adhesive to retain its integrity as long as it takes to reach its purpose. Or the notorious difficulty to generalise the experiences which are lived-through as thoroughly personal and subjective into problems fit to be inscribed into the public agenda and become matters of public policy. These are but few off-hand examples, but they offer a fair view of the kind of challenge now facing sociologists wishing to 'reconnect' their discipline to the public policy agenda. All of them call for a lot of sociological study and meditation, all of them urgently require sociological services.

\section{The second Enlightenment}

At the start of the great modern adventure les philosophes, the prophets and designers of the new - fair, just, reasonable - human order, dreamed of an enlightened despot as the mighty executor of their plans. It was up to the philosophers to draw the right blueprints, and up to the ruler, advised by the philosophers, to make their word flesh by installing the right legal order and enforcing it. That strategy of enlightenment aimed at the all powerful and despotic ruler and the project to change the conditions of the 'ordinary folk' through the ruler's action left it stamp on the social thought of the modern era. Whether enthusiastic or critical about the shape which modern society has taken, social thinkers tended to view society as a whole and every part of it which came under their microscope 'from the top', from the manager's office, from the control desk - as above all a collection of 'problems' to be 'resolved' and an object of administration meant to secure smooth running of daily business and avoidance of friction. Sociology elaborated on that strategic principle - de- 
veloping on the one hand a systemic, and on the other a statistical, demographic view of society, both of practical interest to people undertaking managerial tasks. And the task of every management is to get things done according to plan, whatever are the feelings, wishes and preferences of those whose labour is necessary for the plan's implementation. When society is viewed as an object of management, the 'enlightenment' needed is the art of rendering all potentially disturbing, random factors like intentions and purposes of individuals, harmless - that is, irrelevant to the success of the plan. The idea of 'enlightened despot' captures well the essence of that strategy.

In the 'enlightened despot' version of Enlightenment it is the result - the rationally structured and run society that counts. Individual wills, desires and purposes, individual vis formandi and libido formandi, the poïtic propensity to create new significations with no regard to function, use and purpose are but so many resources, or for that matter obstacles, on the road. But in a democratic society the emphasis and priorities rebel against that perspective: It is precisely those wills, desires and purposes, and their satisfaction, that count and need to be honoured. Democratic society is one that militates against all schemes of perfection imposed against the wishes, or in disregard of the wishes, of the men and women who are embraced by the generic name of 'society'. If despotism means an action undertaken and perpetrated 'from the top', democracy consist in actions arising 'from the bottom up'. The sole 'totality' recognised and acceptable to a democratic society is one emergent out of the actions of creative and freely choosing individuals.

In the service rendered to a demo- cratic society, the kind of enlightenment which sociology is capable of delivering is directed to such freely choosing individuals; sociology is a service to a democratic society in as far as it enhances and reinforces that freedom of choice, reopens rather than closes the work of signification. It is the self-formation of the individual men and women that in the result of sociological enlightenment may gain in fairness, justice and rationality. To do so, or at least to try its best to do so, though, sociology needs a thorough rethinking and rehashing of its orthodox strategy, developed in the service of managerial task. In the words of Cornelius Castoriadis:

an autonomous society, a truly democratic society, is a society which question everything that is pre-given and by the same token liberates the creation of new meaning. In such a society, all individuals are free to create for their lives the meanings they will (and can).... The individualised individual creates the meaning of life while participating in the meanings created by society, participating in their creation, once as an 'author', once as a 'recipient' (public) of those meanings. And I always insist on the fact that true 'reception' of a new work is always as creative as its creation.... (Castoriadis 1996:63).

A truly democratic society, composed of meaning-creating individuals, "knows, must know, that there are no 'assured' meanings, that it lives on the surface of chaos, that it itself is a chaos seeking a form, but a form that is never fixed once for all" (Castoriadis 1996:65). The absence of guaranteed meanings of absolute truths, of preordained 
norms of conduct, of pre-drawn borderlines between right and wrong, of guaranteed rules of successful action - is the condition sine qua non of a truly autonomous society and a truly free individual - while autonomous society and freedom of its members condition each other. Whatever safety democracy and individuality may muster, depends not on fighting the endemic contingency and uncertainty of human condition but on recognizing it and facing its consequences point blank.

This statement goes against the grain of the orthodox strategy putting order, that fore-closure of significations, as the top priority - and from the point of view of that strategy may indeed feel like a mind-boggling paradox. No wonder that whenever sociology is militating against the absolute pretences and the contrived universality of norms it is accused of aiding and abetting moral and cognitive nihilism. But to be against the absolute truth and ultimate foundation does not mean taking side of nihilism. Nihilism - that 'everything goes' posture-means moral indifference seeking justification in the allegedly equal value, and therefore equal worthlessness of competing norms. The human condition which sociology needs to serve is however marked not by the absence of values and valid norms, but precisely by its opposite - by the plurality of norms and values and the awareness that this plurality is an indispensable condition of autonomous society and free individuality - of the values which the allegedly 'nihilistic' sociology put on the top of its agenda. The difference between the orthodox and the new sociology is not between commitment and its absence-but between commitments to different value priorities.

Commitment to the plurality of values and life-meanings does not mean neutrality, nor does it mean indifference to what is being chosen. There are better choices and worse choices; some may be even downright harmful. The point is, however, that without taking risk which polyvocality necessarily entails, without allowing for the freedom of choice which always includes the possibility of wrong and damaging ones, there will be no chance at all for democracy and freedom.

If the orthodox sociology was preoccupied with the conditions of human obedience and conformity - sociology bent on the promotion of autonomy and freedom puts individual responsibility in its focus. The major opposition in a modern 'managed' society was that between conformity and deviance; the major opposition in a late-modern or post-modern democratic, autonomous society is one between taking up responsibility and seeking a shelter where responsibility for one's own action need not be taken by the actor.

Living among a multitude of competing values, norms and life-styles, without any guarantee of 'being in the right', is hazardous and commands high psychological price, and the temptation of the second response, of hiding from the requisites of responsible choice, is today as strong as it never was before. As Julia Kristeva puts it - "it is a rare person who does not invoke a primal shelter to compensate for personal disarray" (Kristeva 1993:2). And we all are, to a greater or lesser extent, sometimes more and sometimes less, in that state of 'personal disarray'. We dream then of a great simplification; we engage on our own account, unprompted, in the 'regressive fantasies' of which the images of pre-natal womb and walled-up home are prime inspirations. The search for a 'primal shelter' is 'the other' of responsibility, just like deviance and 
rebellion were 'the other' of conformity.

Our time is a time of neotribes as much as it is the time of freedom and a time of resentment of difference as much as a time of its enjoyment. Both are born of the same social condition, are bound to share each other's company and can go away only together. Postmodernity is, to put it in the nutshell, a time of constant, everyday choice - for humanity as a whole as much as for the individual men and women. This already renders a noncommittal sociology an impossibility. And indeed seeking a morally neutral stance among the many brands of sociology practiced today, stretching all the way from the outspokenly libertarian and to the staunchly communitarian, would be a vain effort. Sociologists may deny or forget the 'world-view' effects of their work only at the expense of forfeiting that responsibility of choice which every other human being faces daily. What is at stake is our tolerance to difference and solidarity with the different, our readiness to see through the variety of forms of life to the common core of humanity, marked first and foremost by the universal right to one's own identity. What is at stake, in other words, is the new, this time freely built, universality of human beings, resulting from mutual respect of men and women who have freely chosen their own ways of being human. And the job of sociology in all this is to see to it that all the choices are genuinely free, and that they remain such for the duration of humanity.

\section{Bibliography}

Castoriadis, C. 1996: "Le délabrement de I'Occident", in: La Montee de L'insignificance. Paris: Seuil.

Cubitt, S. 1996: "'It is life, Jim, but not as we know it": Rolling Backwards into the Future", in Dovey, J. (ed.) Fractal Dreams: New Media in Social Context. London: Lawrence \& Withart.

Giddens, A. 1996: In Defense of Sociology: Essays, Interpretations $\mathcal{E}$ Rejoinders. Cambridge: Polity Press.

Kristeva, J. 1993: Nations without Nationalism. New York: Comlumbia.

Squares, J. 1996: „,Fabulous Feminist Futures and the Lure of Cyberculture", in Dovey, J. (ed.) Fractal Dreams: New Media in Social Context. London: Lawrence \& Withart. 